\title{
Surgical treatment of isolated fistulae of coronary arteries
}

\author{
Tratamento cirúrgico de fístulas isoladas de artérias coronárias
}

Jorge Alberto Monteiro PORTO ${ }^{1}$, José Pedro Esteves DIAS ${ }^{1}$, Elizabeth Sartori CREVELARI ${ }^{2}$

RBCCV 44205-624

\section{Abstract}

Objective: To report the surgical results obtained with the surgical correction of fistulae of coronary arteries in the pulmonary artery branch.

Method: From 1995 to 1999, three female patients with diagnoses of isolated fistulae of coronary arteries confirmed by cinecoronariography underwent surgery.

Results: No other associated heart diseases were observed in the patients. The main symptom of all patients was angina pectoris. After closing the coronary fistulae the patients progressed with event-free post-operative periods and with total recovery from the angina.

Conclusion: Surgical treatment should be considered for all patients diagnosed as having isolated fistulae, due to the low morbid-mortality rate in addition to the technical simplicity of closing and performing the ligature of fistulae.

Descriptors: Arterio-arterial fistula, surgery. Arterioarterial fistula, congenital. Coronary circulation. Pulmonary artery, surgery

\begin{abstract}
Resumo
Objetivo: Relatar o tratamento cirúrgico das fístulas isoladas de artérias coronárias para o tronco da artéria pulmonar.

Método: No período de 1995 a 1999, três pacientes do sexo feminino com diagnóstico de fístulas isoladas de artérias coronárias, confirmado pela cinecoronariografia, foram tratadas através da abordagem cirúrgica.

Resultados: Os pacientes estudados não apresentavam outras doenças cardíacas associadas. O quadro clínico predominante era de angina pectoris em todos os pacientes. Após o fechamento dos óstios coronários e ligadura das fístulas, com evolução pós-operatória sem intercorrências, os pacientes evoluíram clinicamente assintomáticos, com desaparecimento total do quadro anginoso.

Conclusão: A correção cirúrgica deve ser proposta para os casos diagnosticados de fístulas isoladas de artérias coronárias para evitar complicações importantes, considerando-se a baixa morbi-mortalidade hospitalar e a facilidade técnica para o fechamento e ligadura das fístulas.
\end{abstract}

Descritores: Fístula artério-arterial, cirurgia. Fístula artério-arterial, congênito. Circulação coronária. Artéria pulmonar, cirurgia

\footnotetext{
1 Cardiac Surgery Department of the Panamericano Hospital, São Paulo, SP.

2 Cardiovascular surgery of the pacemaker surgery group of the Instituto do Coração do Hospital das Clínicas of the Medical School of the University de São Paulo. São Paulo, SP.

Correspondence address:

Jorge Alberto Monteiro Porto.

Rua Joaquim Antunes 996, apto 54.

Pinheiros - São Paulo

CEP: 05403-000

Tel: $11-3816.5132 / 96256461$

email: japorto@terra.com.br
} 


\section{INTRODUCTION}

Coronary artery fistulae are a rare form of congenital heart disease, which can cause a communication between one or more coronary arteries with heart chambers, coronary sinus, arteries and pulmonary veins [1].

KRAUSE [2] in 1865 was the first to describe the disease in a case of accessory coronary artery, which drained to the pulmonary vein, and since then more than 400 cases have been reported in publications $[3,4]$. However, with improvements in diagnostic techniques and investigation into heart disease, the incidence of this disease is probably greater. Currently, the incidence is considered to be 1:50,000 congenital heart disease live births and 1:500 submitted to cinecoronariography [4-6].

Coronary artery fistulae can occur in isolation or associated with other heart defects. Isolated fistulae of the right and left coronary arteries commonly finish on the right side of the heart and, less frequently finish on the left side. This latter case does not represent a true arterio-venous "shunt", although presents the same physiological effect of coronary outflow [7].

The right coronary artery and its branches are more commonly involved and represent about $50 \%$ of the isolated cases and 5\% of cases involving both left and right coronary arteries. The left coronary artery is responsible for $42 \%$ of isolated cases [8-13].

The development of these anomalies is generally benign in children, although with the advance of age, some significant complications can occur, such as: early atherosclerosis, myocardial ischemia, congestive heart disease, ventricular arrhythmia, sudden death and coronary artery aneurysms [8,9].

FERNANDES et al. [10] revealed that young patients are generally asymptomatic and the severity of the symptoms is proportional to the size of the "shunt". These patients, when investigated, normally, present with coronary arteries free from obstructive processes and the fistulae are found only by chance [14].

\section{METHOD}

In the period from 1995 to 1999 , three female patients with ages varying from 47 to 52 years old and with diagnoses of coronary arterial fistulae, were submitted to surgical treatment.

In this series, the patients presented with a precordial pain suggestive of pectoris angina as the main symptom, which strongly suggested the presence of obstructive atherosclerotic disease of the coronary arteries. The principal signs and symptoms found are shown in Table 1.

The clinical investigation showed that all the patients had positive results in the physical stress test for myocardial ischemia.
Table 1. Signs and symptoms in patients with isolated coronary artery fistulae

\begin{tabular}{lc}
\hline Signs and Symptoms & \% of patients \\
\hline Angina & 100 \\
Dyspnea & 66.7 \\
Palpitations & 33.3 \\
Congestive heart failure & 66.7 \\
\hline
\end{tabular}

A simple thoracic X-ray evidenced an increase in the cardiac volume and pulmonary vascular trauma in two of the patients but in one it was normal. The diagnosis was confirmed by cinecoronariography.

Neither associated cardiac nor obstructive lesions were found. Two patients presented with isolated right coronary arterial fistulae to the pulmonary artery and the other had bilateral right and left coronary arterial fistulae to the pulmonary branch (Figure 1A and 1B).

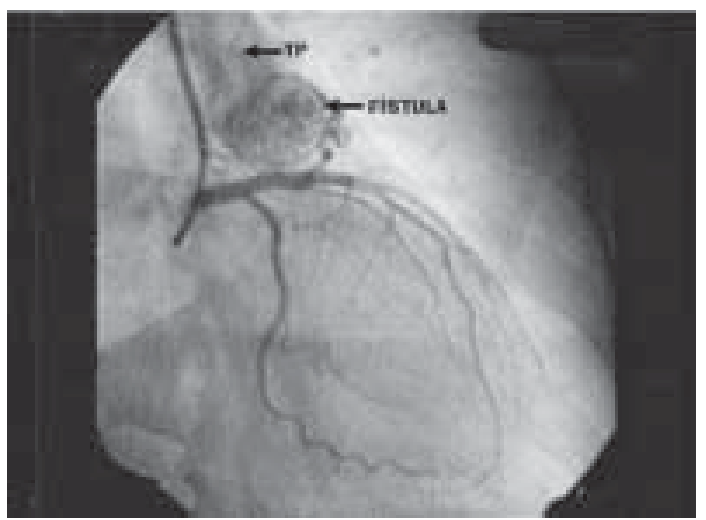

Fig. 1A - Pre-operative angiography demonstrating a left coronary artery fistula to the pulmonary branch (TP) (case 3).

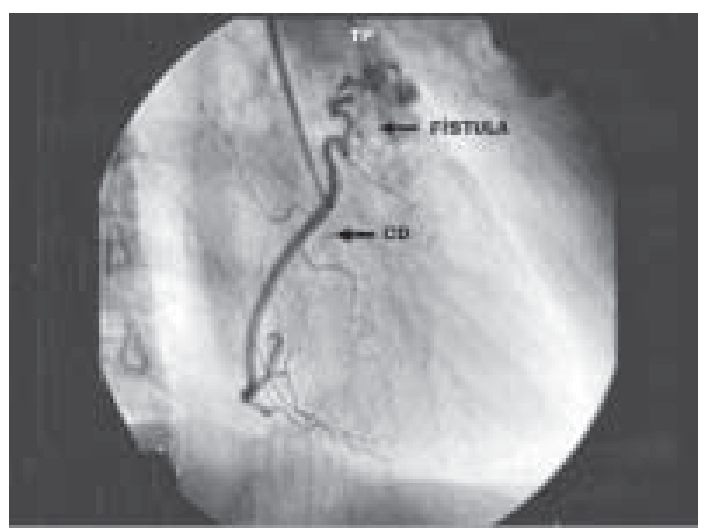

Fig. 1B - Pre-operative angiography demonstration a right coronary artery $(C D)$ fistula to the pulmonary branch. 
All the patients underwent surgical treatment. The approach was by median sternotomy using cardiopulmonary bypass with a venous drain by a single two-part catheter. After aortic clamping, myocardial protection was achieved using St Thomas type anterograde cardioplegia through an aortic puncture and moderate hypothermia $\left(34^{\circ} \mathrm{C}\right)$.

In all cases pulmonary arteriotomy and closure of the fistulae drainage ostia were performed. Ligature of the abnormal vessels, which were the origin of the shunts was only possible in two of the patients. In the other case, the vessels that gave origin to the fistulae presented with a plexiform network which drained into a single orifice above the pulmonary valvular level (Table 2).

The total cardiopulmonary bypass time ranged from 35 to 60 minutes.

Table 2. Origin - site of drainage and adopted procedure

\begin{tabular}{|c|c|c|c|}
\hline Origin & Site of Drainage & $\mathrm{N}^{\circ}$ Patients & Surgical Treatment \\
\hline Right Coronary & Pulmonary Artery & 1 & Ligature + Suture of Ostium \\
\hline Right Coronary & Pulmonary Artery & 1 & Suture of Ostium \\
\hline $\begin{array}{l}\text { Right Coronary } \\
\text { Left Coronary }\end{array}$ & Pulmonary Artery & 1 & Ligature + Suture of Ostium \\
\hline
\end{tabular}

\section{RESULTS}

None of the three patients presented with significant hemodynamic events or complications in the immediate postoperative period.

Electrocardiographic alterations suggestive of myocardial ischemia, a common sign when any coronary branch is obstructed, were not evidenced in this study. The CPK and CKMB-type cardiac enzymes remained at accepted levels for the post-operative period of operations involving coronary arteries.

All the patients were released from the post-operative recovery unit on the third post-operative day and the total hospital stay was from 6 to 8 days.

No hospital mortality was experienced. The cinecoronariography and echocardiogram performed before hospital release revealed the absence of fistulous channels or residual shunts (Figures 2A and 2B).

The outpatient follow-up of these patients, on average was 14 months, showed excellent evolution with the patients remaining asymptomatic, free of angina.

\section{COMMENTS}

Coronary artery fistulae normally have indications for surgical treatment, even though approximately $50 \%$ of the carriers of isolated fistulae are asymptomatic $[11,12,15]$.

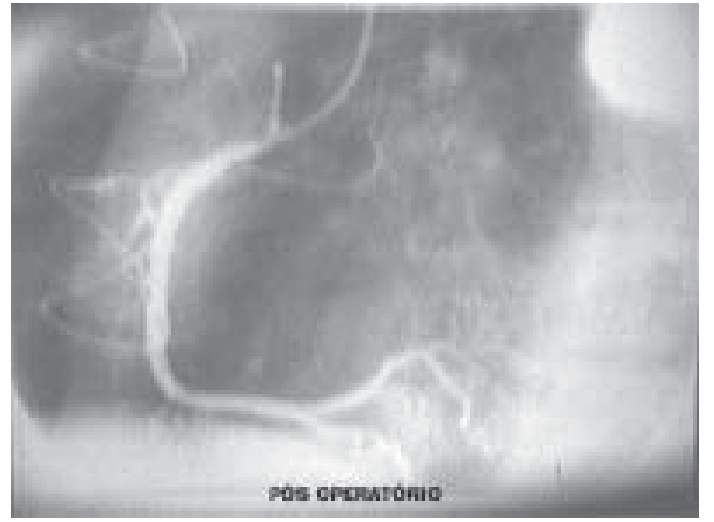

Fig. 2A - Post-operative angiography demonstrating the right coronary artery without fistulae.

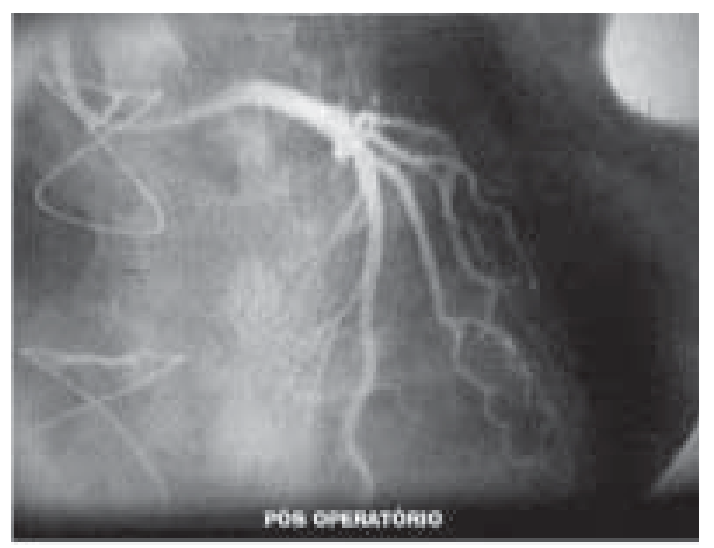

Fig. 2B - Post-operative angiography of the left coronary artery fistula to the pulmonary branch.

The presence of left-right shunts can occasionally lead to the appearance of congestive heart failure, acute myocardial infarction, bacterial endocarditis, formation and rupture of aneurysm and sudden death [13,16-19]. The incidence of these complications increases proportionally with the age of the patients $[3,7,12]$.

The occurrence of angina reported in this series of patients is mainly due to the phenomenon known as coronary outflow, in which there is a clear divergence of coronary flow to the right and/or left chambers. The description in the literature of four patients with angina during exertion [20] and an experimental study in dogs performed by MURAD NETO et al. [14], employing techniques with radioisotopes which proved myocardial ischemia, provide strong evidence that coronary outflow effectively occurs.

Various techniques and surgical tactics for the closure of fistulae have been proposed since the first successful surgery described by BIÖRCK \& CRAFOORD in 1947 [21]. 
The surgical treatment mainly aims at closing the fistulae, correcting the shunt and maintaining the normal coronary flow, preventing the appearance of complications [22].

The use of cardiopulmonary bypass is recommended for the safer surgical treatment of coronary artery fistulae, both for the epicardial ligature and for the closure of intrachamber drainage ostia $[3,15,23]$. Although the epicardial ligature performed on the beating heart, without the use of cardiopulmonary bypass, reduces operative risk [22], the use of suture stabilizers might be a safe option in single, easily accessible fistulae with their drainage ostia well defined by cinecoronariography [22].

The percutaneous closure of fistulae by catheter using embolization or coil might be a treatment option, but this is still under development. Although this treatment has been used in a small and restricted group of patients, there are no studies comparing the results that can guide percutaneous treatment [23-25].

\section{CONCLUSION}

The surgical correction of coronary artery fistulae should be indicated as soon as fistulae are diagnosed in order to treat and prevent the complications of arterio-venous shunts because of the low hospital morbid-mortality rate associated with the procedure.

\section{BIBLIOGRAPHIC REFERENCES}

1. Carrel T, Tkebuchava T, Jenni R, Arbenz U, Turina M. Congenital coronary artery fistulas in children and adults: diagnosis, surgical technique and results. Cardiology 1996; 87: 325-30.

2. Krause W. Ueber den ursprung einer accessorischen $A$. coronaria cordis aus der A. pulmonalis. Z Ratl Med 1865; 24: 225.

3. Urrutia SCO, Falaschi G, Ott DA, Cooley DA. Surgical management of 56 patients with congenital coronary artery fistulas. Ann Thorac Surg 1983; 35: 300-7.

4. Kirklin JW, Barratt-Boyes BG. Congenital anomalies of the coronary arteries. In: Kirklin JW, Barratt-Boyes BG, editores. Cardiac surgery: morphology, diagnostic criteria, natural history, techniques, results and indications. $2^{\text {a }}$ ed. New York: Churchill Livingstone; 1993. p.1167-93.
5. Schumacher G, Roithmaier A, Lorenz HP, Meisner H, Sauer $\mathrm{U}$, Muller KD et al. Congenital coronary artery fistula in infancy and childhood: diagnostic and therapeutic aspects. Thorac Cardiovasc Surg 1997; 45: 287-94.

6. Wenger NK. Rare causes of coronary artery diseases. In: Schlant RC, Alexander RW, O'Rourke RA, Roberts R, Sonnenblick EH, editores. Hurst's the heart. New York: Mc Graw Hill 1978; 1348-9.

7. Sakakibara S, Yokoyama M, Takao A, Nogi M, Gomi H. Coronary arteriovenous fistula: nine operated cases. Am Heart J 1966; 72: 307-14.

8. Castañeda AR, Jonas RA, Mayer Jr. JE, Hanley FL. Coronary artery anomalies: In: Castañeda AR, Jonas RA, Mayer Jr. JE, Hanley FL, editores. Cardiac surgery of the neonate and infant. Philadelphia: WB Sanders; 1994. p. 301-13.

9. Taylor AJ, Rogan KM, Virmani R: Sudden cardiac death associated with isolated congenital coronary artery anomalies. J Am Coll Cardiol 1992; 20:640-7.

10. Fernandes ED, Kadivar H, Hallman GL, Reul GJ, Ott DA, Cooley DA. Congenital malformations of the coronary arteries: the Texas Heart Institute experience. Ann Thorac Surg 1992; 54: $732-40$

11. Rittenhouse EA, Doty DB, Ehrenhaft JL. Congenital coronary artery-cardiac chamber fistula: review of operative management. Ann Thorac Surg 1975; 20: 468-85.

12. Jaffe RB, Glancy DL, Epstein SE, Brown BG, Morrow AG. Coronary artery-right heart fistulae: long-term observations in seven patients. Circulation 1973; 47: 133-43.

13. Liberthson RR, Sagar K, Berkoben JP, Weintraub RM, Levine FH. Congenital coronary arteriovenous fistula: report of 13 patients, review of the literature and delineation of management. Circulation 1979; 59: 849-54.

14. Murad-Netto S, Godoy MG, Rocha AG, Souza WP, Wanderely Neto J, Teixeira JB et al. Coronary artery-left ventricle microshunts: a new technique for its evaluation. Arq Bras Cardiol 1975; 28:587-9.

15. Oldham HN Jr, Ebert PA, Young WG, Sabiston DC Jr. Surgical management of congenital coronary artery fistula. Ann Thorac Surg 1971; 12: 503-13.

16. Daniel TM, Graham TP, Sabiston DC Jr. Coronary arteryright ventricular fistula with congestive heart failure: surgical correction in the neonatal period. Surgery 1970; 67: 985-94.

17. Lim CH, Tan NC, Tan L, Seah CS, Tan D. Giant congenital aneurysm of the right coronary artery. Am J Cardiol 1977; 39: 751-3. 
18. Habermann JH, Howard ML, Johnson ES. Rupture of the coronary sinus with hemopericardium. A rare complication of coronary arteriovenous fistula. Circulation 1963; 28: 1143-4.

19. Bauer HH, Allmendinger PD, Flaherty J, Owlia D, Rossi MA, Chen C. Congenital coronary arteriovenous fistula: spontaneous rupture and cardiac tamponade. Ann Thorac Surg 1996; 62: 1521-3.

20. Ahmed SS, Haider B, Regan TJ. Silent left coronary arterycameral fistula: probable cause of myocardial ischemia. Am Heart J 1982; 104: 869-70.

21. Biörck G, Crafoord C. Arteriovenous aneurysm on the pulmonary artery simulating patent ductus arteriosus Botalli. Thorax 1947; 2: 65-74.
22. Chen Y, Belboul A, Roberts D. The surgical management of congenital coronary artery fistula. Coron Artery Dis 1994; 5: 995-1000.

23. Mavroudis C, Backer CL, Rocchini AP, Muster AJ, Gevitz M. Coronary artery fistulas in infants and children: a surgical review and discussion of coil embolization. Ann Thorac Surg 1997; 63: 1235-42.

24. Reidy JF, Anjos RT, Quareshi SA, Baker EJ, Tynan MJ. Transcatheter embolization in the treatment of coronary artery fistulas. J Am Coll Cardiol 1991; 18: 187-92.

25. Perry SB, Rome J, Keane JF, Baim DG, Lock JE. Transcatheter closure of coronary artery fistulas. J Am Coll Cardiol 1992; 20: 205-9. 